Original Research Paper

\title{
Fatty Acid Profile in Butter from Cows Fed with Sunflower Seeds with or Without Lignosulfonate
}

\author{
${ }^{1}$ Wallacy Barbacena Rosa dos Santos, ${ }^{2}$ Geraldo Tadeu dos Santos, \\ ${ }^{3}$ Daniele Cristina da Silva Kazama, ${ }^{4}$ Tiago Neves Pereira Valente, ${ }^{5}$ Johny Paulo Monteiro, \\ ${ }^{2}$ Francilaine Eloise De Marchi, ${ }^{1}$ Andréia Santos Cezário, ${ }^{1}$ Jeferson Corrêa Ribeiro \\ ${ }^{I}$ Departament of Animal Science, Instituto Federal Goiano, Morrinhos, GO, Brasil \\ ${ }^{2}$ Departament of Animal Science, Universidade Estadual de Maringá, Maringá, PR, Brasil \\ ${ }^{3}$ Departament of Animal Science and Rural Development, Universidade Federal de Santa Catarina, Florianópolis, SC, Brasil \\ ${ }^{4}$ Departament of Animal Science, Instituto Federal Goiano, Posse, GO, Brasil \\ ${ }^{5}$ Departament of Chemistry, Universidade Tecnológica Federal do Paraná, Apucarana - PR, Brasil
}

Article history

Received: 19-11-2019

Revised: $20-03-2020$

Accepted: $15-06-2020$

Corresponding Author:

Tiago Neves Pereira Valente

Departament of Animal

Science, Instituto Federal

Goiano, Posse, GO, Brasil

Email: tiago.valente@ifgoiano.edu.br

\begin{abstract}
The objective of this study was to evaluate the fatty acid composition of butter from Holstein cows fed diets containing ground sunflower seeds or ground and pelleted sunflower seeds, with or without the addition of lignosulfonate. The butter was produced from milk collected from eight Holstein cows multiparous, with $100 \pm 62.6$ days in milk, with a mean weight of $556 \pm 39.8 \mathrm{~kg}$ Body Weight (BW) and producing 15.6 \pm 0.12 $\mathrm{kg}$ of Milk/day. The cows were distributed in a double Latin square, with 4 periods of 21 days each, with 14 days for adaptation and seven days for data collection. Diets containing pelleted sunflower seeds altered the fatty acids profile of the butter, with an increase in the fatty acids $16: 1 \mathrm{n}-11$, 18:1trans and CLA18:2 c9 t11. However, decreased the amounts of fatty acids 18:0 and 20:0. The amounts of Saturated Fatty Acids (SFA) decreased, while the Polyunsaturated Fatty Acids (PUFA) and the amount of total Conjugated Linoleic Acid (CLA) increased with the pelleted diet. Thus, the use of diets with pelleted sunflower seeds is possible to obtain butter with desirable nutritional value in dairy products, which are beneficial for consumer health.
\end{abstract}

Keywords: Conjugated Linoleic Acid, Dairy Products, Pellet, Polyunsaturated Fatty Acids

\section{Introduction}

Several foods with natural components rich in nutrient pharmaceutical properties are studied to prevent diseases (Tanaka, 2005), present only in vegetables. However, Conjugated Linoleic Acid (CLA) is the exception because it is exclusively present in ruminant products. The CLA represents a group of isomers of linoleic acid, which is found in derivatives of ruminants. The CLA 18:2c9t11 is a featured isomer with interesting nutritional properties and improves human health by reducing body fat and preventing hyperglycemia (Barendse, 2014). According to Hernández et al. (2007), fatty acid profiles demonstrates that CLA is a stable component in the dairy products and concluded that dietary supplementation of sunflower seed in cows increases the CLA contents in butter, which may contribute to the reduction of the risk of cardiovascular diseases in humans.

When formulating concentrates for ruminants, is important increase the energy density of the diet (Mir et al., 2003). Lipid supplements are frequently included in ruminant diets for increase the energy density of the diet while simultaneously increasing the nutrient utilization (Mangrum et al., 2016).

The sunflower seeds are rich in Polyunsaturated Fatty Acids (PUFA), mainly linoleic fatty acid, with $47 \%$ oil in the composition. According to Figueiroa et al. (2013) with $11 \%$ of Saturated Fatty Acids (SFA), 27\% Monounsaturated (MUFA) and 60\% Polyunsaturated (PUFA), $60.5 \%$ of which are linoleic acid. The addition of either sunflower whole seeds or oil to lactating goats ration had beneficial effects on milk yield and milk composition with enhancing milk content of healthy 
fatty acids (CLA and omega 3), without detrimental effects on animal performance (Morsy et al., 2015).

Biohydrogenation occurs in rumen, by ruminal microorganisms, against the toxicity of Unsaturated Fatty Acids (UFAs) (Valente et al., 2016). The PUFA such as C18:2 have a diene double bond configuration, in the rumen environment occurs the first step in the biohydrogenation process. Is an isomerization reaction that converts the cis-12 double bond of UFAs into a trans-11 isomer. The last step of the biohydrogenation process is the reduction of vaccenic acid to stearic acid (C18:0). The extent to which trans-11 $\mathrm{C} 18: 1$ is hydrogenated to $\mathrm{C} 18: 0$ depends on the conditions that are prevalent in the rumen. Complete hydrogenation to stearic acid is promoted by the presence of ruminal fluid and feed particles and is inhibited irreversibly by the presence of large amounts of linoleic acid (Berg et al., 2006).

There are some ways of protecting dietary ingredients by avoiding contact with ruminal microorganisms, reducing ruminal biohydrogenation. Among the methods, pelleting can improve the nutrient utilization efficiency of feeds, which also improvement the production of milk and dairy products (Neves et al., 2007). The heat treatment may protect partially the biohydrogenation of linoleic acid. Studies on the feeding of dairy cows with the supply of soybean and canola grains thermally treated confirm the increase in the concentration of isomer 18:2 c9 t11 (Neves et al., 2009). The lignosulfonate is a by-product from the wood industry, enzymatic agglomerate rich in xylose and can be added to the ruminant diet with the aim of reducing ruminal biohydrogenation and support the pelletizing process (Figueiroa et al., 2013). The addition of lignosulfonate to the diet of dairy cows had no negative effect on dry matter intake, milk production, milk concentrations of Crude Protein (CP), lactose and total solids (Santos et al., 2011). Among the properties of lignosulfonate its potential to be combined with proteins. Petit et al. (1999) utilized fat soybeans and lignosulfonate and observed that lignosulfonate reduced the ruminal degradation of proteins, thus increasing the levels ruminal nondegradable proteins by protecting them from the activity of rumen microorganisms and a decrease in Dry Matter (DM) digestibility upon increased temperature and the addition of lignosulfonate. The established hypotheses are: It is possible to improve the fatty acid profile of milk and dairy products by supplying sunflower seeds to dairy cows; Physical treatments and chemical properties of sunflower seeds may reduce the appearance of saturated fatty acids in butter. The objective of this study was to evaluate the fatty acid profile in milk butter from Holstein cows fed diets containing sunflower seeds or pelleted sunflower seeds, with or without lignosulfonate addition, under grazing conditions.

The established hypotheses are: It is possible to improve the fatty acid profile of milk and dairy products by supplying sunflower seeds to dairy cows; Physical treatments and chemical properties of sunflower seeds may reduce the appearance of saturated fatty acids in butter. The objective of this study was to evaluate the fatty acid profile in milk butter from Holstein cows fed diets containing sunflower seeds or pelleted sunflower seeds, with or without lignosulfonate addition, under grazing conditions.

\section{Materials and Methods}

\section{Experimental Site}

The study was carried out in Experimental Farm of Iguatemi (FEI), at the State University of Maringá, Brazil. Located at $23^{\circ} 21^{\prime} 19.2^{\prime \prime} \mathrm{S}, 52^{\circ} 04^{\prime} 22.8^{\prime \prime} \mathrm{W}$, average altitude of $551 \mathrm{~m}$. The climate of the region is classified as Cfa by the Köppen classification (humid subtropical climate).

\section{Animal Management, Feeding and Treatment}

A group of eight Holstein cows multiparous, with $100 \pm 62.6$ days of milk, with a mean weight of $556 \pm 39.8$ $\mathrm{kg}$ body weight (BW) and producing $15.6 \pm 0.12 \mathrm{~kg}$ of Milk/day. The cows were distributed in a double Latin square, with 4 periods of 21 days each, with 14 days for adaptation to diet and seven days for data collection.

The diets consisted of four concentrates, with the sunflower seed (only ground or ground and pelleted) and the addition or not of lignosulfonate, in a $2 \times 2$ factorial arrangement.

The experimental diets were: 1- Ground sunflower seeds (S); 2- Ground sunflower seeds with addition of lignosulfonate (SL); 3- Ground sunflower seeds and pelleted (SP); 4- Ground Sunflower seeds with addition of Lignosulfonate and Pelleted (SLP). Nutritional composition of the diets is shown in Table 1.

Sunflower seeds used in the four concentrates were ground through a $5 \mathrm{~mm}$ screen using a Nogueira ${ }^{\circledR}$ DPM- 2 chopper and added at $427.4 \mathrm{~g} / \mathrm{kg}$ of dry matter (DM). The lignosulfonate solution was prepared with Lignosol $\left(\right.$ Melbar $\left.^{\circledR}\right)$ and had $740 \mathrm{~g} / \mathrm{kg}$ and contained 27 $\mathrm{g} / \mathrm{kg} \mathrm{DM}$ of xylose. The lignosulfonate solution was added at $50 \mathrm{~g} / \mathrm{kg}$ DM after grinding the seeds. Pelleting of concentrates for treatments was with a $40 \mathrm{HP}$ pelleting machine (Chavantes ${ }^{\circledR}$ ) without steam addition at a $75^{\circ} \mathrm{C}$ exit temperature. Yield averaged $900 \mathrm{~kg} / \mathrm{h}$ and the die diameter was $4.5 \mathrm{~mm}$. New batches of concentrates were made for each of the four periods but the same lot of ground sunflower seeds was used for the whole experiment. 
Table 1: Percentage composition of the diets on a dry matter (DM) basis

\begin{tabular}{|c|c|c|c|c|}
\hline \multirow[b]{2}{*}{ Ingredients (\%) } & \multicolumn{4}{|c|}{ Treatment } \\
\hline & $S$ & SL & $\mathrm{SP}$ & SLP \\
\hline Soybean meal & 23.14 & 23.14 & 23.14 & 23.14 \\
\hline Cracked corn & 22.53 & 22.53 & 22.53 & 22.53 \\
\hline Dicalcium phosphate & 4.70 & 4.70 & 4.70 & 4.70 \\
\hline Mineral mix and vitamin ${ }^{a}$ & 3.10 & 3.10 & 3.10 & 3.10 \\
\hline Sodium bicarbonate & 1.55 & 1.55 & 1.55 & 1.55 \\
\hline Limestone & 1.40 & 1.40 & 1.40 & 1.40 \\
\hline $\mathrm{NaCl}$ & 0.84 & 0.84 & 0.84 & 0.84 \\
\hline Ground sunflower seeds & 42.74 & - & - & - \\
\hline Ground sunflower seeds with addition of lignosulfonate & - & 42.74 & - & - \\
\hline Ground sunflower seeds and pelleted & - & - & 42.74 & - \\
\hline Ground sunflower seeds with addition of lignosulfonate and pelleted & - & - & - & 42.74 \\
\hline
\end{tabular}

${ }^{\mathrm{a}} \mathrm{Ca} 270$ g/kg, P 80 g/kg, S 20 g/kg, Mg, 15 g/kg, Fe 2200 mg/kg, Cu 800 mg/kg, Co 50 mg/kg, I 60 mg/kg, Se: 40 mg/kg, Zn 2800 $\mathrm{mg} / \mathrm{kg}$, F $801 \mathrm{mg} / \mathrm{kg}$, Vit. A 216000 U.I./kg, Vit. D 67600 U.I./kg, Vit. E 500 mg/kg

Cows were kept in pasture of (Cynodon dactylon $(\mathrm{L}$. Pers.) cultivars Coast Cross (CC) and Bermuda Grass (BG). Four periods were used for the study. Grazing was initiated when pasture height equaled or exceeded $30 \mathrm{~cm}$ and terminated at a height of $20 \mathrm{~cm}$. Cows were individually fed experimental concentrates for a $45 \mathrm{~min}$ period after each milking. Intake of concentrates was recorded for each cow after each feeding and amounts offered were adjusted to allow $100 \mathrm{~g} / \mathrm{kg}$ refusals as fed. Milk production was recorded at every milking.

Pasture samples were obtained on day 15 and 21 after throwing a metallic square with dimension $\left(1.0 \mathrm{~m}^{2}\right)$ three times within the most recently grazed paddock $(\mathrm{n}=12$ samples/intake period). Samples of pasture were pooled on a period basis by paddock to obtain one sample/period for chemical analysis. Pastures were grazed to a $20 \mathrm{~cm}$ stubble height. Composite samples of concentrates, refusals and pasture were mixed thoroughly and sub-sampled for chemical analysis.

The Forage: Concentrate ratio was 70:30. The diets were formulated to be isoproteic and isoenergetic, based on ethereal extract, according to NRC (2001). The cows received concentrate feed individually in a Tie stall barn, in two meals per day at 8 and $16 \mathrm{~h}$, immediately after morning and afternoon milking, remaining for about $45 \mathrm{~min}$ at a time.

To maintain the Forage: Concentrate ratio of feed intake, it was necessary to calculate fecal output, a capsule of chromic oxide $\left(\mathrm{Cr}_{2} \mathrm{O}_{3}\right)$ was inserted into the rumen of the fistulated cows $(n=4)$ and given orally to the non-fistulated cows $(\mathrm{n}=4)$ once daily at $09: 00 \mathrm{~h}$ from day 11 to 20, supplying a total of $15 \mathrm{~g}$ of $\mathrm{Cr}_{2} \mathrm{O}_{3} / \mathrm{d}$. Samples of feces $(100 \mathrm{~g})$ were collected from all cows for 6 consecutive days at 08:00, 10:00, 12:00, 14:00, 16:00 and 18:00 $\mathrm{h}$ of each experimental period, respectively, for days $15-20$ and kept frozen $\left(-20^{\circ} \mathrm{C}\right)$. Fecal samples were dried at $55^{\circ} \mathrm{C}$ for $48 \mathrm{~h}$ and ground to pass a $1 \mathrm{~mm}$ screen in a Wiley mill. Equal DM from each fecal sub-sample was mixed to obtain a single composite for each sampled cow during each experimental period. After thawing, samples of feed and forage were weighed and oven dried at $60^{\circ} \mathrm{C}$ for $72 \mathrm{~h}$. Then, samples were processed in a Wiley® knife mill to pass through 1-mm screen sieves and stored in plastic bags. Samples were analyzed for DM, CP, Ether Extract (EE) and Mineral Matter (MM) according to the Association of Official Analytical Chemists (AOAC, 1990), neutral detergent fiber assayed with heat stable amylase and expressed exclusive of residual ash (aNDFom-NDF), Acid Detergent Fiber expressed exclusive of residual ash (ADFom-ADF) and acid method of fiber analysis. In the aNDFom-NDF analyses, thermostable $\alpha$-amylase was used without sodium sulfite, using an Ankom ${ }^{\circledR}$ fiber extractor, according to Valente et al. (2015). Non-Fiber Carbohydrates (NFCs) in the ingredients of the diets were determined by the following equation:

$$
\begin{aligned}
& \mathrm{NFC}=100-(\% \text { aNDFom-NDF+\%CP+\%EE+ } \\
& \% \mathrm{MM}) \text {, according to Sniffen } \text { et al. }(1992) .
\end{aligned}
$$

Indigestible aNDFom-NDF was used as an internal marker to estimate pasture intake (Cochran et al., 1986). Preparation of pasture, concentrate, orts and fecal residues from in situ incubation followed by aNDFom-NDF extraction was similar to the technique described by Ellis et al. (1984) for preparation of indigestible aNDFomNDF (aNDFom-NDF remaining after $144 \mathrm{~h}$ of in situ incubation). Fecal output (DMbasis) was calculated from marker concentration using the following formula:

$$
\begin{aligned}
& \text { Fecal output }(\mathrm{g} / \mathrm{d})=\mathrm{Cr} \text { dose }(\mathrm{mg} / \mathrm{d}) / \mathrm{Cr} \text { in } \\
& \text { feces }(\mathrm{mg} / \mathrm{g} \text { feces }) .
\end{aligned}
$$

The contribution of pasture to fecal output was estimated after total fecal output was corrected for contribution of the concentrate by subtracting the indigestible aNDFom-NDF fraction of concentrate from 
total fecal output. The indigestible aNDFom-NDF content of pasture and feces was used as an internal marker to estimate intake using the following formula:

Pasture DM int ake $(\mathrm{kg} / \mathrm{d})$

((indigestibleaNDFom - NDF in feces, $\mathrm{kg} / \mathrm{d})-($ indigestible aNDFom - NDF inconcentrate, $\mathrm{kg} / \mathrm{d}))$ (indigestible aNDFom - NDF in forage $(\mathrm{kg} / \mathrm{kg}$ forage $)$ )

Estimated metabolizable energy and Net Energy of lactation (NEl). For (ME; in Mcal kg-1 of DM) was determined according to the National Research Council (NRC, 2001).

The average composition of the pasture in the experimental period is shown in Table 2 and the total diet in Table 3.

In Table 4 shows the analysis of the fatty acid profiles of the concentrate of each diet and in Table 5 is the analysis of the fatty acid profiles of the pasture of the Cynodon dactylon (L.) Pers. Cv. Tifton-85.

Table 2: Mean chemical composition of pasture (Cynodon dactylon (L.) Pers.) as percentage dry matter (DM), organic matter (OM), Crude Protein (CP), Ether Extract (EE), Neutral Detergent fiber (aNDFom-NDF), Acid Detergent Fiber (ADFom-ADF) and Mineral Matter (MM), for Cultivars Coastcross (CC) and Bermudagrass (BG)

\begin{tabular}{lllllll}
\hline Item $\%^{1}$ & Cultivars $^{2}$ & Period 1 & Period 2 & Period 3 & Period 4 & ${\text { Mean } \pm \mathrm{SD}^{3}}^{2}$ \\
\hline DM & CC & 27.21 & 25.80 & 27.42 & 27.70 & $27.03 \pm 0.85$ \\
& BG & 27.00 & 26.79 & 26.94 & 27.42 & $27.04 \pm 0.27$ \\
OM & CC & 92.99 & 92.16 & 92.71 & 93.65 & $92.88 \pm 0.62$ \\
& BG & 92.07 & 92.14 & 92.79 & 93.28 & $92.57 \pm 0.57$ \\
CP & CC & 20.59 & 20.15 & 23.66 & 20.76 & $21.29 \pm 1.60$ \\
& BG & 18.50 & 18.25 & 23.71 & 16.10 & $19.14 \pm 3.23$ \\
EE & CC & 2.00 & 2.26 & 2.08 & 2.10 & $2.11 \pm 0.11$ \\
& BG & 2.28 & 3.20 & 2.00 & 1.30 & $2.20 \pm 0.79$ \\
aNDFom-NDF & CC & 72.24 & 73.69 & 70.79 & 74.70 & $72.86 \pm 1.71$ \\
& BG & 70.60 & 70.71 & 71.22 & 75.94 & $72.12 \pm 2.56$ \\
ADFom-ADF & CC & 36.36 & 36.15 & 33.64 & 38.25 & $36.10 \pm 1.89$ \\
\multirow{2}{*}{ MM } & BG & 35.33 & 36.68 & 37.09 & 36.44 & $36.39 \pm 0.75$ \\
& CC & 7.01 & 7.84 & 7.29 & 6.35 & $7.12 \pm 0.62$ \\
& BG & 7.93 & 7.86 & 7.21 & 6.72 & $7.43 \pm 0.57$ \\
\hline
\end{tabular}

1. DM = dry matter; $\mathrm{OM}=$ organic matter; $\mathrm{CP}=$ crude protein; $\mathrm{EE}=$ ether extract; aNDFom-NDF = neutral detergent fiber; ADFom$\mathrm{ADF}=$ acid detergent fiber; and $\mathrm{MM}=$ mineral matter.

$2-\mathrm{CC}=$ Coastcross; $\mathrm{BG}=$ Bermudagrass.

3- SD $=$ Standard deviation

Table 3: Mean chemical composition of experimental diets for Total Digestibility Nutrient (TDN), Energy Net of lactation (NEl), Dry Matter (DM), Organis Matter (OM), Crude Protein (CP), Ether Extract (EE), Neutral Detergent Fiber (aNDFom-NDF), Acid Detergent Fiber (ADFom-ADF), Nonfiber Carbohydrates (NFCs) and Mineral Matter (MM)

\begin{tabular}{|c|c|c|c|c|}
\hline & \multicolumn{4}{|l|}{ Diets $^{1}$} \\
\hline & $\mathrm{S}$ & SL & SP & SLP \\
\hline $\mathrm{TDN}^{2}(\%)$ & 69.27 & 70.05 & 69.79 & 69.91 \\
\hline $\mathrm{NEl}^{3}(\mathrm{Mcal} / \mathrm{kgDM})$ & 1.58 & 1.59 & 1.59 & 1.59 \\
\hline $\mathrm{DM}(\%)$ & 52.98 & 53.32 & 54.32 & 52.31 \\
\hline $\mathrm{OM}(\%)$ & 94.21 & 93.91 & 94.03 & 93.42 \\
\hline $\mathrm{CP}(\%)$ & 22.52 & 21.72 & 21.67 & 21.19 \\
\hline $\mathrm{EE}(\%)$ & 8.02 & 8.28 & 8.37 & 7.36 \\
\hline aNDFom-NDF (\%) & 52.96 & 52.87 & 51.79 & 53.73 \\
\hline ADFom-ADF (\%) & 27.14 & 27.24 & 27.05 & 27.26 \\
\hline $\mathrm{NFCs}^{4}(\%)$ & 17.41 & 19.34 & 19.38 & 20.36 \\
\hline $\mathrm{MM}(\%)$ & 8.88 & 8.73 & 8.92 & 8.74 \\
\hline
\end{tabular}

${ }^{1}$ Ground sunflower seeds (S); Ground Sunflower seeds with addition of Lignosulfonate (SL); Ground sunflower seeds and pelleted (SP); Ground Sunflower seeds with addition of Lignosulfonate and Pelleted (SLP).

${ }^{2} \mathrm{TDN}=$ Total digestible nutrients, estimated in the feed composition according to the NRC (2001), considering that $1 \mathrm{~kg}$ of total digestible nutrients (TDNs) contains 4.409 Mcal of Digestible Energy (DE), with the factor 0.82 used in the conversion from DE to metabolizable energy(ME).

${ }^{3} \mathrm{NEl}=$ Net energy of lactation. The amount of energy in a feed which is available for milk production and body maintenance.

${ }^{4} \mathrm{NFCs}=$ Nonfiber carbohydrates in the ingredients of the diets were determined by the following equation: NFC $=100-(\%$ aNDFom $-\mathrm{NDF}+\% \mathrm{CP}+\% \mathrm{EE}+\% \mathrm{MM})$, according to Sniffen et al. (1992). 
Table 4: Fatty acid profile in concentrate diets; Ground sunflower seeds (S); Ground Sunflower seeds with addition of Lignosulfonate (SL); Ground Sunflower seeds and Pelleted (SP); Ground Sunflower seeds with addition of Lignosulfonate and Pelleted (SLP)

\begin{tabular}{|c|c|c|c|c|}
\hline \multirow[b]{2}{*}{ Fatty acid profile } & \multicolumn{4}{|c|}{ Treatment } \\
\hline & $\mathrm{S}$ & SL & SP & SLP \\
\hline \multicolumn{5}{|l|}{ (\% total lipid) } \\
\hline $16: 0$ & 8.19 & 9.09 & 8.26 & 8.94 \\
\hline 18:0 & 5.97 & 6.79 & 5.92 & 6.71 \\
\hline $18: 1 n-9$ & 19.55 & 20.91 & 20.13 & 20.10 \\
\hline $18: 1 n-7$ & 0.63 & 0.68 & 0.69 & 0.72 \\
\hline $18: 2 n-6$ & 65.13 & 61.87 & 64.45 & 62.93 \\
\hline $18: 3 n-3$ & 0.53 & 0.65 & 0.55 & 0.59 \\
\hline
\end{tabular}

Table 5: Fatty acid profile in pasture of the Cynodon dactylon (L.) Pers

\begin{tabular}{|c|c|c|c|c|}
\hline \multirow[b]{2}{*}{ Fatty acid profile } & \multicolumn{4}{|c|}{ Treatment } \\
\hline & Period 1 & Period 2 & Period 3 & Period 4 \\
\hline \multicolumn{5}{|l|}{ (\% total lipid) } \\
\hline $16: 0$ & 25.49 & 25.53 & 25.50 & 25.51 \\
\hline $18: 0$ & 11.34 & 11.35 & 11.32 & 11.33 \\
\hline $18: 1 n-9$ & 8.96 & 8.93 & 8.97 & 8.94 \\
\hline $18: 1 n-7$ & 0.98 & 0.98 & 1.00 & 0.99 \\
\hline $18: 2 n-6$ & 14.33 & 14.34 & 14.36 & 14.34 \\
\hline $18: 3 n-3$ & 38.91 & 38.89 & 38.88 & 38.91 \\
\hline
\end{tabular}

\section{Experimental Procedures}

For butter production, 10 liters of milk were collected, proportionally to the morning and afternoon production of each animal. The collected milk was packaged in a plastic bucket and stored at $4^{\circ} \mathrm{C}$ for $24 \mathrm{~h}$ for cream precipitation. After $24 \mathrm{~h}$, the cream was removed and stored in plastic containers for further pasteurization at $75^{\circ} \mathrm{C}$ for $30 \mathrm{~min}$ according to Kazama et al. (2010). After pasteurization, the samples were immediately cooled to $4^{\circ} \mathrm{C}$ for $20 \mathrm{~h}$ and beaten in a separate mixer until they turned into butter.

The total fat was extracted with a solution of chloroform-methanol-water (2:2:1.8 v/v/v) according to Bligh and Dyer (1959). Were weighed $15 \mathrm{~g}$ of sample in a $250 \mathrm{~mL}$ beaker, adding $45.0 \mathrm{~mL}$ of chloroformmethanol solution $(1: 2 \mathrm{v} / \mathrm{v})$ and stirred for about $5 \mathrm{~min}$. Thereafter, were added to the mixture $15.0 \mathrm{~mL}$ of chloroform and stirred for $2 \mathrm{~min}$ and $18.0 \mathrm{~mL}$ of distilled water, stirring for $5 \mathrm{~min}$.

The solution obtained was vacuum filtered on a Büchner funnel with Whatman ${ }^{\circledR}$ quantitative filter paper. The residue retained on the filter paper was transferred to the beaker and added $30 \mathrm{~mL}$ of chloroform and $30 \mathrm{~mL}$ of $\mathrm{H}_{2} \mathrm{O}$, then another stirring was performed.

The filtration procedure was repeated, the resulting solution being transferred to a $250 \mathrm{~mL}$ separatory funnel. After phase separation, chloroform and fat material were drained to a pre-weighed $250 \mathrm{~mL}$ Claisen flask. The solvent is removed on a rotary evaporator under reduced pressure and kept in water bath in temperature up to $30^{\circ} \mathrm{C}$. The solvent residue was discarded with nitrogen flow. The fat material content in the flask was weighed and the lipid content determined gravimetrically.

Fat in butter was separated by centrifugation as described by Murphy et al. (1995) and fatty acids in milk fat were methylated according to method 5509 (ISO, 1978) using $\mathrm{KOH} /$ methanol (Synth ${ }^{\circledR}$ ) and $\mathrm{n}$-heptane (Vetec $\left.{ }^{\circledR}\right)$. Fatty acid methyl ester profiles were measured at a split ratio of 1:100 by GLC on a Varian chromatograph (Palo Alto, CA, USA) with a G1315A auto sampler equipped with a flame ionization detector and a CP-7420 fused silica capillary column $(100 \mathrm{~m}$ and $0.25 \mathrm{~m}$ film thickness). The column parameters were: Initial column temperature of $65^{\circ} \mathrm{C}$ was maintained for $4 \mathrm{~min}$; the temperature was then programmed at $20^{\circ} \mathrm{C} / \mathrm{min}$ to $170^{\circ} \mathrm{C}$; this temperature was maintained for $22 \mathrm{~min}$ and then increased $6^{\circ} \mathrm{C} / \mathrm{min}$ to $235^{\circ} \mathrm{C}$ and remained at this temperature for $12 \mathrm{~min}$. Injector and detector temperatures were 220 and $240^{\circ} \mathrm{C}$, respectively. The carrier gas was hydrogen at 1.2 $\mathrm{ml} / \mathrm{min}$. Hydrogen flow to the detector was $30 \mathrm{ml} / \mathrm{min}$, airflow was $300 \mathrm{ml} / \mathrm{min}$ and the flow of $\mathrm{N}_{2}$ make-up gas was $30 \mathrm{ml} / \mathrm{min}$. Fatty acid peaks were identified using pure methyl ester standards of the CLA isomers cis9,trans11-18:2 and trans10,cis12-18:2 (cat\#05632; Sigma-Aldrich ${ }^{\circledR}$ ) and a commercial mixture of fatty acids (cat\#18919; Sigma-Aldrich ${ }^{\circledR}$ ). Separations of all fatty acids were obtained in a single chromatographic run. The calculations were performed according to the Joseph and Ackman (1992). 


\section{Statistical Procedures and Model Evaluation}

All results were analyzed using the MIXED procedure of SAS (2003) within a $2 \times 2$ factorial arrangement of treatments, analyzed using a replicated $4 \times 4$ Latin square design with the general model:

$$
Y_{i j k l m}=\mu+T_{i}+P_{j}+S_{k}+A_{l}+T S_{i k}+P S_{j k}+A / S_{l k}+e_{i j k l m}
$$

Where:

$Y_{i j k l m}=$ The dependent variable, $\mu=$ overall mean

$T_{i} \quad=$ Treatment effect $(\mathrm{S}, \mathrm{SL}, \mathrm{SP}$ and SLP)

$P_{j} \quad=$ Effect of period (1, 2, 3 and 4)

$S_{k} \quad=$ Effect of latin square (1-2)

$A_{1} \quad=$ Effect of animal (1-8)

$T S_{\mathrm{ik}}=$ Interaction between the diet and the latin square

$P S_{j k}=$ Interaction between the period and the latin square

$A / S_{l k}=$ Animal effect nested inside the latin square

$e_{i j k l m}=$ Residual error

Significance was declared at $\mathrm{P} \leq 0.05$ and a trend was accepted at $0.05<\mathrm{P} \leq 0.10$.

\section{Results}

Treatments with pelleted sunflower seeds provided a tendency $(\mathrm{P}=0.09)$ to reduce the amounts of 14:1n-7 (3.99 vs $4.44 \mathrm{~g} / 100 \mathrm{~g}$ of total lipids), while tending to 17:0 (5.70 vs. $5.20 \mathrm{~g} / 100 \mathrm{~g}$ total lipids) known as margic acid (Table 6).

The fatty acids 16:1n-11, 18:0, 18:1trans (transvaccinic acid), 20:0 and CLA 18:2c9t11 had effects according to treatments.

The pelleted diets increased $(\mathrm{P}<0.05)$ in the concentrations of fatty acids $16: 1 \mathrm{n}-11$ (2.85 vs 1.76$)$, 18:1 trans (87.15 vs 48.03) and CLA 18:2c9t11 (22.75 vs.10.96). However, decreased the amounts of SFA 18:0 (172.92 vs 207.90) e 20:0 (1.74 vs 1.93 ). No difference for the other fatty acids influenced by diets.

The presence of lignosulfonate in the treatments studied does not affect the composition of fatty acids in butter.

The sum and ratios between groups fatty acids in butter, for the different treatments, is shown in Table 7. Pelleted diets had lower amounts of SFA, CLA total and PUFA $(424.05,12.32,52.49)$, respectively, when compared to non-pelleted diets $(468.59,24.15,60.05)$.

Table 6: Fatty acid profile of butter of cows kept in pasture, supplemented with ground sunflower seeds (S); ground sunflower seeds with addition of lignosulfonate (SL); ground sunflower seeds and pelleted (SP); ground sunflower seeds with addition of lignosulfonate and pelleted (SLP)

\begin{tabular}{|c|c|c|c|c|c|c|c|c|}
\hline \multirow[b]{2}{*}{ Fatty acid profile } & \multicolumn{4}{|c|}{ Treatment } & \multirow[b]{2}{*}{$\mathrm{SE}^{2}$} & \multicolumn{3}{|c|}{ Probability $^{1}$} \\
\hline & $\mathrm{S}$ & SL & SP & SLP & & $\mathrm{L}$ & $\mathrm{P}$ & I \\
\hline \multicolumn{9}{|l|}{$\mathrm{mg} / \mathrm{g}$ total lipid } \\
\hline $4: 0$ & 7.03 & 7.47 & 7.18 & 6.07 & 0.98 & 0.73 & 0.53 & 0.43 \\
\hline $6: 0$ & 3.73 & 3.84 & 4.02 & 3.31 & 0.47 & 0.53 & 0.79 & 0.39 \\
\hline $8: 0$ & 2.54 & 2.61 & 2.65 & 2.23 & 0.31 & 0.58 & 0.67 & 0.44 \\
\hline 10:0 & 6.03 & 6.13 & 6.33 & 5.28 & 0.70 & 0.50 & 0.70 & 0.42 \\
\hline $12: 0$ & 8.46 & 8.46 & 9.01 & 7.87 & 0.75 & 0.46 & 0.98 & 0.46 \\
\hline $14: 0$ & 43.99 & 44.45 & 45.47 & 40.75 & 3.51 & 0.55 & 0.76 & 0.47 \\
\hline $14: 1 n-9$ & 4.83 & 5.25 & 4.76 & 4.57 & 0.37 & 0.77 & 0.32 & 0.42 \\
\hline $14: 1 n-7$ & 4.63 & 4.25 & 4.18 & 3.80 & 0.25 & 0.16 & 0.09 & 0.98 \\
\hline $15: 0$ & 9.41 & 8.47 & 9.59 & 9.03 & 0.46 & 0.11 & 0.43 & 0.68 \\
\hline $15: 1 n-7$ & 1.78 & 1.69 & 1.65 & 1.55 & 0.09 & 0.32 & 0.17 & 0.94 \\
\hline $16: 0$ & 169.64 & 174.87 & 160.56 & 168.04 & 6.07 & 0.30 & 0.20 & 0.85 \\
\hline $16: 1 n-11$ & 1.87 & 1.65 & 2.61 & 3.09 & 0.31 & 0.67 & 0.01 & 0.26 \\
\hline $16: 1 n-9$ & 6.07 & 8.50 & 7.11 & 7.43 & 0.96 & 0.16 & 0.99 & 0.28 \\
\hline $16: 1 n-7$ & 3.16 & 3.07 & 3.04 & 3.08 & 0.15 & 0.86 & 0.71 & 0.64 \\
\hline 17:0 & 4.98 & 5.42 & 5.54 & 5.85 & 0.22 & 0.19 & 0.07 & 0.76 \\
\hline $17: 1 n-7$ & 1.59 & 1.93 & 1.77 & 2.05 & 0.24 & 0.21 & 0.55 & 0.90 \\
\hline 18:0 & 210.83 & 204.97 & 172.12 & 173.72 & 8.88 & 0.73 & 0.01 & 0.60 \\
\hline $18: 1$ trans & 51.99 & 44.06 & 89.10 & 85.19 & 5.88 & 0.39 & 0.01 & 0.73 \\
\hline $18: 1 n-9$ & 315.63 & 324.69 & 308.26 & 323.11 & 9.45 & 0.22 & 0.64 & 0.76 \\
\hline $18: 1 n-7$ & 2.22 & 2.98 & 2.42 & 2.48 & 0.36 & 0.26 & 0.68 & 0.34 \\
\hline $18: 2$ trans & 5.80 & 5.29 & 6.14 & 5.90 & 0.29 & 0.22 & 0.12 & 0.66 \\
\hline $18: 2 n-6$ & 36.80 & 35.82 & 32.99 & 30.99 & 2.57 & 0.65 & 0.13 & 0.75 \\
\hline $18: 3 n-6$ & 0.96 & 0.94 & 0.96 & 1.05 & 0.06 & 0.52 & 0.39 & 0.40 \\
\hline $18: 3 n-3$ & 2.86 & 2.96 & 2.88 & 2.94 & 0.21 & 0.70 & 0.98 & 0.90 \\
\hline 20:0 & 1.95 & 1.91 & 1.76 & 1.72 & 0.09 & 0.66 & 0.04 & 0.97 \\
\hline CLA18:2c9t11 & 11.09 & 10.83 & 23.74 & 21.76 & 2.22 & 0.63 & 0.01 & 0.72 \\
\hline CLA18:2t10c12 & 1.37 & 1.35 & 1.43 & 1.35 & 0.06 & 0.41 & 0.66 & 0.66 \\
\hline
\end{tabular}

1. L- Lignosulfonate Effect, P- Pelletizing Effect, I- Interaction.

2- SE- Standard error 
Table 7: The sum and ratios between groups fatty acids in butter of cows kept in pasture, supplemented with ground sunflower seeds (S); ground sunflower seeds with addition of lignosulfonate (SL); ground sunflower seeds and pelleted (SP); ground sunflower seeds with addition of lignosulfonate and pelleted (SLP)

\begin{tabular}{|c|c|c|c|c|c|c|c|c|}
\hline \multirow[b]{2}{*}{ Fatty acid groups ${ }^{3}$} & \multicolumn{4}{|c|}{ Treatment } & \multirow[b]{2}{*}{$\mathrm{SE}^{2}$} & \multicolumn{3}{|c|}{ Probability $^{1}$} \\
\hline & $\mathrm{S}$ & SL & SP & SLP & & $\mathrm{L}$ & $\mathrm{P}$ & I \\
\hline \multicolumn{9}{|l|}{$\mathrm{mg} / \mathrm{g}$ total lipid } \\
\hline SFA & 468.59 & 468.60 & 424.23 & 423.87 & 9.95 & 0.97 & 0.01 & 0.96 \\
\hline MUFA & 341.78 & 354.01 & 335.80 & 351.16 & 9.93 & 0.19 & 0.67 & 0.88 \\
\hline PUFA & 53.08 & 51.90 & 62.00 & 58.09 & 3.67 & 0.57 & 0.05 & 0.69 \\
\hline Omega 6 & 37.16 & 36.77 & 33.96 & 32.04 & 3.62 & 0.66 & 0.13 & 0.77 \\
\hline Omega 3 & 2.86 & 2.96 & 2.89 & 2.94 & 0.21 & 0.70 & 0.98 & 0.90 \\
\hline Omega 6/Omega 3 & 13.22 & 12.70 & 12.02 & 11.28 & 0.83 & 0.45 & 0.12 & 0.89 \\
\hline CLA total & 12.46 & 12.18 & 25.18 & 23.12 & 2.22 & 0.60 & 0.01 & 0.69 \\
\hline
\end{tabular}

1- L- Lignosulfonate Effect, P- Pelletizing Effect, I- Interaction.

2. SE = Standard error

3- SFA = saturated fatty acid, MUFA, monounsaturated fatty acids, PUFA, polyunsaturated fatty acids, CLA = conjugated linoleic acid

\section{Discussion}

In a similar study using, lignosulfonate treatment of concentrates containing ground sunflower seeds, Santos et al. (2011) observed little effect on milk production and milk composition in our cows which averaged 15.1 $\mathrm{kg} / \mathrm{d}$ of milk production. This lack of response supports prior observations that treatments such as lignosulfonate have little effect on milk production and composition of low yielding cows. However, cows fed pelleted concentrates had lower milk fat concentration than those fed non-pelleted concentrates, pelleting had no effect on total tract apparent digestibility of nutrients. Pelleting had more effects than lignosulfonate treatment on milk fatty acid profile, with concentrations of trans11-18:1 and CLA, respectively $178 \%$ and $200 \%$ of those found in milk fat of cows fed non-pelleted concentrates. Pelleting may contribute to improved nutritional value of concentrates containing sunflower seeds as a source of CLA precursors, although there is no additive or synergistic effect between lignosulfonate treatment and pelleting. Similar result found in the present study, when contrasting the different treatments. The pelleting process protects the nutrients of rumen microorganisms and increases the level of non-degradable proteins in the rumen. Heating modifies the amino acid residues of proteins through reactions with other compounds or through cross-linking (Petit et al., 1999). Xylose, which is present in lignosulfonate, can react with several amino groups and this reaction decreases ruminal protein degradation, therefore protecting the proteins from the activity of rumen microorganisms. However, lignosulfonate and pelleting could contribute to release of oils in the rumen, improving the digestibility of nutrients and the milk production of dairy cows. Thus, studies to minimize the negative effects of high fat addition and increase PUFA uptake in milk are important to improve the impact of sunflower seeds use on ruminant nutrition (Marchi et al., 2013).
According to Table 4, the composition in the fatty acids of the treatments is characteristic of diets containing sunflower seeds. With a mean of $63.59 \%$ of $18: 2 n-6$ and the lipid composition of the butter of the cows were similar the fatty acids presents into the milk and kept after the butter was produced. Figueiroa et al. (2013) pelleted concentrates containing sunflower seeds can be used for producing milk with a lower fat content in Holstein cows. Although, the pelleting process or lignosulfonate addition are not effective in protecting the Unsaturated Fatty Acids (UFAs) of the diet or improving the milk fatty acid and butter texture. Middaugh et al. (1988) tested the use of diets based on sunflower seeds fed to Holstein cows and observed an increase in the UFAs content in milk fat and, consequently, a higher amount of these fatty acids in the butter.

The presence of lignosulfonate in the treatments studied does not affect the composition of fatty acids in butter. Neves et al. (2007) feeding cows with extruded versus non-extruded soybeans, observed decreased milk fat concentration and concentrations of SFA in milk fat, while it increased concentrations of CLA in milk fat. Concentrations of cis9, trans11 CLA and PUFA tended to be increased by lignosulfonate treatment of full-fat soybeans. But that lignosulfonate treatment has less important effects on the milk fatty acid profile, similar result found in the present study.

The lignosulfonate protects fatty acids against ruminal biohydrogenation (Wright et al., 2005; Neves et al., 2009) and may alter the composition of fatty acids in butter (Santos et al., 2011). It is possible that an expressive amount of UFAs present in the pelleted treatments occurred partial biohydrogenation in the rumen observed in butter, higher amounts of intermediates of this process, such as 18:1 trans and trans 11, cis9-18:2 (CLA). According to Harfoot and Hazlewood (1997) the final result of ruminal biohydrogenation is stearic acid. This process can be considered a barrier in the incorporation of unsaturated fatty acids to the milk and its derivatives. 
However, according to several research results it is possible to reduce the effects of bacteria on the UFAs contained in the diet, through chemical or physical processing (Chouinard et al., 1997; Silva et al., 2007). With the results obtained in this experiment, pelleting can reduce biohydrogenation of fatty acids. The increase of one of the intermediates of this process, 18: 1 trans, is one of the reasons that can justify this assertion, since this intermediate was found almost double the amount, in the butter of the cows that received the pelleted diets. The higher amounts of trans11, cis9-18: 2 (CLA) in the butter of animals receiving heat-treated diets are extremely interesting results. For the health of the consumed this butter is relevant, since CLA has been related to anticarcinogenic, antiatherogenic effects, increase of the immune response, reduction of accumulated fat in the body and also, antidiabetic effect (Whigham et al., 2000; Tanaka, 2005).

The synthesis of conjugated linoleic acid occurs with the presence of the Delta 9-desaturase enzyme in the mammary gland. The precursor is 18: 1 trans, intermediate of the biohydrogenation of linoleic and $\alpha$ linolenic acids (Tanaka, 2005). The values found for trans11, cis9-18: 2 in higher quantity with pelleting may be the greater amount of trans 18:1 (twice more) available in the mammary gland. Increases in 18: 1 trans and CLA (all isomers) in butter when they provided sunflower co-products in the diet of lactating cows when compared to the control treatment (Bauman et al., 1999).

Diet rich in oleaginous grains may increase ruminal biohydrogenation, consequently the presence of SFA. However, by using protective techniques of unsaturated fatty acids present in the diet, against this process, it is possible to incorporate these in the products of ruminants (meat, milk and dairy products).

The animals that received pelleted diets had higher PUFA values and lower SFA values. The results obtained in this experiment confirm those found by Bauman et al. (1999).

The composition of the fatty acids of the butter can alter its characteristics, mainly of texture, in a greater amount of UFAs responsible for a softer and lighter color butter (Cavalieri et al., 2005). In these experiments fatrich PUFA were provided to dairy cows for the production of butter, this fact is similar to the present study because the sunflower is an oleaginous rich in UFAS and also present in butter. Bett et al. (2005) also found PUFA values higher than SFA, in a study with dairy cows fed diets with sunflower seeds.

CLA corresponds to the group of linoleic acid isomers which are present in foods produced by ruminants. CLA presents important nutraceutical properties and add greater nutritional value and consequent improvement of human health (Barendse, 2014). The MUFA and PUFA are directly related to a healthy diet of humans, since, balanced human diets are recommended the ingestion of more UFAs (omega 3 and CLA) (Lima et al., 2017). The consumption of foods rich in UFAs, such as butter, may be responsible for the reduction in the incidence of cardiovascular diseases (Sangiovanni et al., 2000; Bucher et al., 2002; Lorgeril and Salen, 2002), prevention of arteriosclerosis and thrombosis, resulting from the modification of lipid metabolism (Petit, 2002).

\section{Conclusion}

Diets with pelleted sunflower seeds modify the fatty acid composition of butter and increase CLA18:2c9t11.

The heat treatment used in pelleted diets reduces the amount of SFA and increases PUFA.

Diets with lignosulfonate do not modify the fatty acid profile in butter.

\section{Funding Information}

This research was funded by Universidade Estadual de Maringá and IFGoiano, Brazil.

\section{Author's Contributions}

Wallacy Barbacena Rosa dos Santos, Daniele Cristina da Silva Kazama, Johny Paulo Monteiro and Francilaine Eloise De Marchi: designed and carried out the experiment.

Geraldo Tadeu dos Santos, Tiago Neves Pereira Valente andréia Santos Cezário and Jeferson Corrêa Ribeiro: Critically analysed the manuscript and provided guidance. Additionally, the authors have read and approved the final version of this manuscript.

\section{Conflict of interest}

The authors declare that they have no conflict of interest related to this study.

\section{References}

AOAC, 1990. Official Methods of Analysis. 15th Edn., Association of Official Analytical Chemists, Arlington VA.

Barendse, W., 2014. Should animal fats be back on the table? A critical review of the human health effects of animal fat. Anim. Produc. Sci., 54: 831-855. DOI: $10.1071 /$ AN13536

Bauman, D.E., L.H. Baumgard, B.A. Corl and J.M. Griinari, 1999. Biosynthesis of conjugated linoleic acid in ruminats. Proceeding of the American Society of Animal Science, (SAS' 99), Cornell University, pp: 1-15.

Berg, J.M., J.L. Tymoczko and L. Stryer, 2006. Biochemistry. 6th Edn., W.H. Freeman and Company, New York, pp: 1026. 
Bett, V., M.D.S. Oliveira, M. Matsushita, S.A. Headley and N.E. Souza, 2005. Effects of sunflower oilseed supplementation on the fatty acid profile and milk composition from Holstein cows. Acta Scientiarum, 26: 95-101.

Bligh, E.G. and W.J. Dyer, 1995. A rapid method of total lipid extraction and purification. Canadian J. Biochem. Physiol., 37: 911-917.

DOI: 10.1139/y59-099

Bucher, H.C., P. Hengstler, C. Schindler and G. Meier, 2002. Reviews: n-3 polyunsaturated fatty acids in coronary heart disease: A meta-analysis of randomized controlled trials. Am. J. Med., 112: 298-304. DOI: 10.1016/S0002-9343(01)01114-7

Cavalieri, F.L.B., G.T. Santos, M. Matsushita, H.V. Petit and L.P. Rigolon et al., 2005. Short Communication: Milk production and milk composition of dairy cows fed Lac $100^{\circledR}$ or whole flaxseed. Can. J. Anim. Sci., 85: 413-416.

DOI: 10.4141/A04-088

Chouinard, P.Y., V. Girard and G.J. Brisson, 1997. Performance and profiles of milk fatty acids of cows fed full fat, heat-treated soybeans using various processing methods. J. Dairy Sci., 80: 334-342. DOI: $10.3168 /$ jds.S0022-0302(97)75943-5

Cochran, R.C., D.C. Adams, J.D. Wallace and M.L. Galyean, 1986. Predicting digestibility of different diets with internal markers: Evaluation of four potential markers. J. Anim. Sci., 63: 1476-1483. DOI: $10.2527 /$ jas 1986.6351476x

Ellis, W.C., E.M. Bailey and C.A. Taylor, 1984. A silicone esophageal cannula; its surgical installation and use in research with grazing cattle, sheep or goats. J. Anim. Sci., 59: 204-209.

DOI: $10.2527 /$ jas $1984.591204 x$

Figueiroa, F.J.F., F.E. Marchi, G.T. Santos, W.B.R. Santos and D.C.S. Kazama et al., 2013. Production, composition and fatty acid profile of milk and butter texture of dairy cows fed ground or pelleted concentrate with sunflower and/or lignosulphonate.

Braz. J. Anim. Sci., 42: 743-750.

DOI: $10.1590 / \mathrm{S} 1516-35982013001000008$

Harfoot, C.G. and G.P. Hazlewood, 1997. Lipid Metabolism in the Rumen. In: The Rumen Microbial Ecosystem, Hobson, P.N. and C.S. Stewart, (Eds.), Blackie Academic and Professional, Great Britain, pp: 382-426.

Hernández, E.R., M.M. Jácome, R.G. Lee, T. Nakano and L. Ozimek et al., 2007. High Conjugated Linoleic Acid (CLA) content in milk and dairy products using a dietary supplementation of sunflower seed in cows. Thrombogenic/atherogenic risk issues. Arch. Latinoam. Nutr. 57: 173-178.
ISO, 1978. Animal and vegetable fats and oils Preparation of methyl esters of fatty acids. Method ISO 5509, International Organization for Standardization, Geneve.

Joseph, J.D. and R.G. Ackman, 1992. Capillary column gas chromatographic method for analysis of encapsulated fish oils and fish oil ethyl esters: Collaborative study. J. AOAC Int., 75: 488-506. 10.1093/jaoac/75.3.488

Kazama, D.C.S., G.T. Santos, P.T.M. Pintro, J.V. Visentainer and R. Kazama et al., 2010. Effect of storage on fatty acid profile of butter from cows fed whole or ground flaxseed with or without monensin. Braz. J. Anim. Sci., 39: 2297-2303. DOI: 10.1590/S1516-35982010001000028

Lima, E.S., T.N.P. Valente, R.O. Roça, A.S. Cezário and W.B.R. Santos et al., 2017. Effect of whole cottonseed or protected fat dietary additives on carcass characteristics and meat quality of beef cattle: A review. J. Agri. Sci., 9: 175-189.

DOI: $10.5539 /$ jas.v9n5p175

Lorgeril, M.D. and P. Salen, 2002. Fish and n-3 fatty acids for the prevention and treatment of coronary heart disease: Nutrition is not pharmacology. Am. J. Med., 112: 316-319. DOI: 10.1016/S0002-9343(02)01020-3

Mangrum, K.S., G. Tuttle, S.K. Duckett, G.S. Sell and C.R. Krehbiel et al., 2016. The effect of supplementing rumen undegradable unsaturated fatty acids on marbling in early-weaned steers1. J. Anim. Sci., 94: 833-844. DOI: 10.2527/jas.2015-9809

Marchi, F.E., F.J.F. Figueiroa, G.T. Santos, W.B.R. Santos and D.C.S. Kazama et al., 2013. Intake, digestibility and ruminal parameters of dairy cows fed pelleted diets and treated with lignosulfonatecontaining sunflower seeds. Braz. J. Anim. Sci., 42: 656-663. DOI: 10.1590/S1516-35982013000900008

Middaugh, R.P., R.J. Baer, D.P. Casper, D.J. Schingoethe and S.W. Seas, 1988. Characteristics of milk and butter from cows fed sunflower seeds. J. Dairy Sci., 71: 3179-3187.

DOI: 10.3168/jds.S0022-0302(88)79922-1

Mir, P.S., T.A. McAllister, S. Zaman, S.D. Morgan Jones and M.L. He et al., 2003. Effect of dietary sunflower oil and vitamin $\mathrm{E}$ on beef cattle performance, carcass characteristics and meat quality. Can. J. Anim. Sci., 83: 53-66.

DOI: 10.4141/A02-014

Morsy, T.A., S.M. Kholif, A.E. Kholif, O.H. Matloup and A.Z. Salem et al., 2015. Influence of sunflower whole seeds or oil on ruminal fermentation, milk production, composition and fatty acid profile in lactating goats. Asian Australas J. Anim. Sci., 28: 1116-1122. DOI: 10.5713 /ajas. 14.0850 
Murphy, J.J., J.F. Connolly and G.P. McNeill, 1995. Effects of milk fat composition and cow performance of feeding concentrates containing full fat rapeseed and maize distillers grains on grasssilage based diets. Livest Prod. Sci., 44: 1-11. DOI: 10.1016/0301-6226(95)00049-Q

Neves, C.A., G.T. Santos, M. Matsushita, E.M. Alves and R.L. Oliveira et al., 2007. Intake, whole tract digestibility, milk production and milk composition of Holstein cows fed extruded soybeans treated with or without lignosulfonate. Anim. Feed Sci. Technol., 134: 32-44. DOI: 10.1016/j.anifeedsci.2006.05.015

Neves, C.A., W.B.R. Santos, G.T. Santos, D.C. Silva and C.C. Jobim et al., 2009. Production performance and milk composition of dairy cows fed extruded canola seeds treated with or without lignosulfonate. Anim. Feed Sci. Technol., 154: 83-92.

DOI: $10.1016 /$ j.anifeedsci.2009.08.002

NRC, 2001. Nutrient Requirements of Dairy Cattle. 7th Edn., National Academy of Sciences, Washington D.C., USA, pp: 381

Petit, H.V., G.F. Tremblay, M. Marcotte and R. Audy, 1999. Degradability and digestibility of full-fat soybeans treated with different sugar and heat combinations. Canad. J. Anim. Sci., 79: 213-220. DOI: 10.4141/A98-106

Petit, H.V., 2002. Digestion milk production milk composition and blood composition of dairy cows fed whole flaxseed. J. Dairy Sci., 85: 1482-1490. DOI: $10.3168 /$ jds.S0022-0302(03)73859-4

SanGiovanni, J.P., C.S. Berkey, J.T. Dwyer and G.A. Colditz, 2000. Review Dietary essential fatty acids, long-chain polyunsaturated fatty acids and visual resolution acuity in healthy fullterm infants: A systematic. Early Human Dev., 57: 165-188. DOI: $10.1016 / \mathrm{S} 0378-3782(00) 00050-5$

Santos, W.B.R., G.T. Santos, D.C.S. Kazama, U. Cecato and J.V. Visentainer et al., 2011. Production performance and milk composition of grazing dairy cows fed pelleted or non-pelleted concentrate treated with or without lignosulfonate and containing ground sunflower seeds. Anim. Feed Sci. Technol., 169: $167-175$.

DOI: 10.1016/j.anifeedsci.2011.06.015

SAS, 2003. User's guide. SAS Institute In., Cary, NC, USA.

Silva, D.C., G.T. Santos, A.F. Branco, J.C. Damasceno and R. Kazama et al., 2007. Production performance and milk composition dairy cow fed whole or ground flaxseed with or without monensin. J. Dairy Sci., 90: 2928-2936.

DOI: $10.3168 /$ jds.2009-92-8-500
Sniffen, C.J., D.J. O’Connor, P.J. Van Soest, D.G. Fox and J.B. Russel, 1992. A net carbohydrate and protein system for evaluating cattle diets: II: Carbohydrate and protein availability. J. Anim. Sci., 70: 3562-3577. DOI: 10.2527/1992.70113562x

Tanaka, K., 2005. Occurrence of conjugated linoleic acid in ruminant products and its physiological functions. Anim. Sci. J., 76: 291-303.

DOI: $10.1111 /$ j.1740-0929.2005.00268.x

Valente, T.N.P., E. Detmann and C.B. Sampaio, 2015. Review: Recent advances in evaluation of bags made from different textiles used in situ ruminal degradation. Canad. J. Anim. Sci., 95: 493-49.

DOI: 10.4141/CJAS-2015-100

Valente, T.N.P., E.S. Lima, W.B.R. Santos, A.S. Cezário and C.J. Tavares et al., 2016. Ruminal microorganism consideration and protein used in the metabolism of the ruminants: A Review. African J. Microbiol. Res., 10: 456-464.

DOI: 10.5897/AJMR2016.7627

Whigham, L.D., E. Mark, B. Cook and R.L. Atkinson, 2000. Conjugated linoleic acid: Implications for human health. Pharmacol. Res., 42: 503-510. DOI: $10.1006 /$ phrs.2000.0735

Wright, C.F., M.A.G. Keyserlingk, M.L. Swift, L.J. Fisher and J.A. Shelford et al., 2005. Heat and lignosulfonate treated canola meal as a source of ruminal undegradable protein for lactating dairy cows. J. Dairy Sci., 88: 238-243.

DOI: $10.3168 /$ jds.S0022-0302(05)72681-3

\section{Abbreviations}

ADFom-ADF, acid detergent fiber expressed exclusive of residual ash; aNDFom-NDF, neutral detergent fiber assayed with a heat stable amylase and expressed exclusive of residual ash; CLA, conjugated linoleic acid; $\mathrm{CP}$, crude protein; DM, dry matter; EE, ether extract; MM, mineral matter; MUFA, monounsaturated fatty acids; NFCs, nonfiber carbohydrates; PUFA, polyunsaturated fatty acids; SFA, saturated fatty acids; TDN, total digestible nutrients. UFAs, unsaturated fatty acids. 